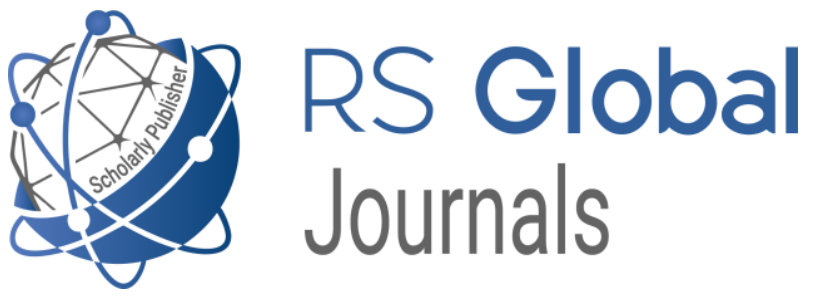

Scholarly Publisher

RS Global Sp. z O.O.

ISNI: 0000000484952390

Dolna 17, Warsaw, Poland 00-773

Tel: +48226022703

Email: editorial_office@rsglobal.pl

JOURNAL International Journal of Innovative Technologies in Social Science

p-ISSN $2544-9338$

e-ISSN

2544-9435

PUBLISHER

RS Global Sp. z O.O., Poland

ЗВ' ЯЗКИ МІЖ ІМПЛІЦИТНОЮ ТЕОРІЕЮ СВІДОМОСТІ ТА ОСОБИСТІСНИМИ ВЛАСТИВОСТЯМИ В УМОВАХ

ARTICLE TITLE НОРМИ ТА ПРИ ЗАЛЕЖНОСТІ ВІД ПСИХОАКТИВНИХ РЕЧОВИН

$\operatorname{AUTHOR}(\mathbf{S})$

ARTICLE INFO

DOI

RECEIVED

ACCEPTED

PUBLISHED

LICENSE
Тельчаров Олександр

Oleksandr Telcharov. (2021) Coherence Between the Theory of Mind and Personality Traits in the Conditions of Norm and in Dependence on Psychoactive Substances. International Journal of Innovative Technologies in Social Science. 1(29). doi: 10.31435/rsglobal_ijitss/30032021/7483

https://doi.org/10.31435/rsglobal_ijitss/30032021/7483

16 January 2021

14 March 2021

19 March 2021

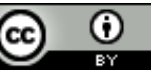

This work is licensed under a Creative Commons Attribution

4.0 International License.

(C) The author(s) 2021. This publication is an open access article. 


\title{
ЗВ'ЯЗКИ МІЖ ІМПЛІЦИТНОЮ ТЕОРІЕЮ СВІДОМОСТІ ТА ОСОБИСТІСНИМИ ВЛАСТИВОСТЯМИ В УМОВАХ НОРМИ ТА ПРИ ЗАЛЕЖНОСТІ ВІД ПСИХОАКТИВНИХ РЕЧОВИН
}

\author{
Тельчаров Олександр, аспірант кафедри Психодіагностики та Клінічної психології, \\ факультет психології, Київський наџіональний університет імені Тараса Шевченка, Київ, \\ Украӥна, ORCID ID: https://orcid.org/0000-0002-3381-6693
}

DOI: https://doi.org/10.31435/rsglobal_ijitss/30032021/7483

\section{ARTICLE INFO}

Received 16 January 2021

Accepted 14 March 2021

Published 19 March 2021

\section{KEYWORDS}

Theory of Mind, persons dependent on psychoactive substances, Alcoholic Anonymous, alexithymia, conditional norm, personality traits.

\begin{abstract}
The term Theory of Mind (ToM) refers to the cognitive ability to understand the persons' own and others' intentions, emotions, feelings, beliefs, and so on. This psychological ability has been studied mainly in the context of normal development, in the conditions of normal ontogenesis, as well as on the example of animals, children with atypical development, adults with certain mental disorders. There are also studies related to some specifics of ToM in people dependent to alcohol. The aim of the article is to establish correlations between ToM and personality traits in the conditions of norm and dependence on psychoactive substances (PAS). The study was conducted on 98 individuals. 42 are people dependent on PAS and are stand at the initial stage of recovery, 15 people are dependent on PAS at a later stage of recovery and 41 people which are a group of conditional norm. The nonparametric method of $\mathrm{r}$ Spearman rank correlation coefficient is used. As a result, established a number of links between ToM and personality traits during the comparison the data of persons dependent on PAS and conditional norm persons It is setted that the dependence on PAS has a negative effect on ToM. ToM is related the most to the fifth factor "Expressiveness-Practice" of the 5PFQ Personal Questionnaire. The second external correlate of ToM, which is expressed more in the early stages of recovery from PAS, can be considered as the second factor of the Personality Questionnaire 5PFQ "Attachment-Isolation". The assumption has been made that the ToMC scale has the most valuable biological correlates and the strongest expression with personality traits. The age trait is strongly related to the ToM scales linearly.
\end{abstract}

Citation: Oleksandr Telcharov. (2021) Coherence Between the Theory of Mind and Personality Traits in the Conditions of Norm and in Dependence on Psychoactive Substances. International Journal of Innovative Technologies in Social Science. 1(29). doi: 10.31435/rsglobal_ijitss/30032021/7483

Copyright: (C) 2021 Oleksandr Telcharov. This is an open-access article distributed under the terms of the Creative Commons Attribution License (CC BY). The use, distribution or reproduction in other forums is permitted, provided the original author(s) or licensor are credited and that the original publication in this journal is cited, in accordance with accepted academic practice. No use, distribution or reproduction is permitted which does not comply with these terms.

Вступ. Імпліцитна теорія свідомості належить до відносно нових конструктів, за допомогою яких описується здатність пояснювати зміст власної свідомості та свідомості інших. Термін «Theory of Mind» [14], який є оригінальним терміном для позначення даної психічної властивості, позначає пізнавальну здатність розуміти як свої власні, так і чужі наміри, емоції, почуття, переконання тощо. Завдяки цій здатності вищі примати і люди можуть краще взаємодіяти у соціальних ситуаціях, де необхідні аналіз, оцінка та розуміння поведінки інших [11]. Теоретичні моделі та підходи до іiі вивчення, тим не менш, не привели до появи несуперечливої спільної позиції [10].

Як зазначають Е. Дубяга та Б. Мещеряков [1], у російськомовній літературі переклад оригінального терміна зустрічається у різних варіантах, наприклад, «індивідуальна теорія психіки», «теорія розпізнавання психічних станів», «життєва психологія», «наївна концепція 
свідомості», «внутрішня модель свідомості іншого» тощо, у той час як і в англомовній літературі $\epsilon$ багато синонімів терміна «Theory of Mind»: «інтенціональність другого порядку», «метарепрезентація», «наївна психологія», «природна психологія» тощо.

Самі автори (Е. Дубяга та Б. Мещеряков) пропонують для позначення змісту, що передається оригінальним терміном, російськомовний аналог «имплицитная теория разума». Нам ця точка зору видається слушною, і українською мовою ми позначатимемо цей конструкт терміном «імпліцитна теорія свідомості» (далі - ITC).

Цю психологічну здатність на сьогоднішній день досліджено більшою мірою у контексті типового розвитку, тобто в умовах нормального онтогенезу, а також на прикладі тварин, дітей 3 нетиповим розвитком, дорослих 3 певними психічними розладами. Існують також дослідження, які стосуються специфіки ITC у осіб, залежних від алкоголю. Багато з них здійснені з використанням методів когнітивної нейронауки.

У метааналізі Onuoha et al., (2016) показано, що у осіб, залежних від ПАР, ІTC є редукованою [13]. Було встановлено, що для цієї категорії осіб характерний насамперед афективний дефіцит ITC, який відбиває, на думку дослідників, ураження відповідних ділянок мозку як наслідок тривалого вживання алкоголю. В низці досліджень $[7 ; 2 ; 3 ; 4]$ встановлено зміни у афективних процесах осіб, залежних від психоактивних речовин (далі - ПАР), зокрема, у проявах алекситимії.

У іншій групі досліджень $[16 ; 11 ; 15 ; 12]$ виокремлено основні способи та результати дослідження ITC за умов норми та патології. Тим не менш, слід зазначити, що серед вітчизняних публікацій практично відсутні роботи, присвячені цій психологічній здатності, хоча дослідження ITC є украй актуальними для різних галузей психології. На нашу думку, до найбільш актуальних напрямів досліджень ITC на вітчизняній вибірці слід віднести встановлення параметрів цієї здатності у нормі та ії специфіки в умовах залежності від ПАР. Адже саме залежність від ПАР постає сьогодні як проблема, що потребує залучення додаткових ліній розгляду та аналізу, оскільки вже протягом багатьох десятиліть показники стійкої ремісії при психічних та поведінкових розладах внаслідок вживання ПАР не демонструють позитивної динаміки [5].

Метою статті $є$ встановлення зв'язків між ITC та особистісними властивостями в умовах норми та залежності від ПАР.

Ми припускаємо, що залежність від ПАР лінійно пов'язана зі здатністю до побудови ITC та проявляється у гірших результатах осіб, залежних від ПАР, у порівнянні з особами, які не мають такої залежності.

Матеріали та методи. Дослідження проводилося на 98 особах 3 них 42 - особи, залежні від ПАР та початковому етапі одужання (27 осіб, залежних від алкоголю та 15 осіб, залежних від інших ПАР), які на момент дослідження перебували на лікуванні у реабілітаційному центрі «Медлюкс», м. Київ. Усі досліджувані мали у анамнезі попередній епізод тривалого вживання ПАР не більше, ніж за 3 тижні до моменту проведення дослідження. Група осіб, залежних від ПАР, на початковому етапі одужання складалась 3 таких категорій: 1) особи, залежні від алкоголю (код МКБ F10), 2) особи, залежні від психостимуляторів (код МКБ F15), 3) особи, залежні від одночасного вживання декількох наркотичних засобів (код МКБ F19.2). Цю групу вибірки скорочено позначатимемо у тексті ЗПАР.

Наступну групу склали 15 осіб, залежних від алкоголю, які мали в анамнезі систематичне вживання ПАР, проте від 1 місяця до 15 років не вживають жодних ПАР, тобто знаходяться на більш пізніх етапах одужання. Ці досліджувані $є$ членами українського співтовариства Анонімних Алкоголіків, скорочено позначатимемо їх $A A$ Ще одну групу, групу умовної норми, утворили 41 умовно здорова особа: у них не було виявлено залежності від ПАР. ІІї позначатимемо $У Н$.

53 особи у дослідницькій вибірці - чоловіки, 45 - жінки. Серед групи ЗПАР, 34 чоловіки та 8 - жінки. Серед групи АА, 14 - чоловіки та 1 особа - жінка. Серед групи УН жінки - 36 осіб та чоловіки -5 . Отже, слід зазначити гендерну негомогенність груп, тому можливий вплив на результати фактора статі.

Вік досліджуваних - від 19 до 70 років, медіана - 35 років, $\mathrm{SD}=14.2$. Третина вибірки (35,7\%) знаходиться у діапазоні $20-22$ роки, а $81,6 \%$ - від 20 до 50 років. Тобто вибірка не гомогенна також і за фактором віку. Однак, окрім вікової групи 20-22, більша частина якої належить до УН, у дослідницькій вибірці репрезентовані різні вікові категорії, тому припускаємо, що фактор віку не має бути істотним. 
Для дослідження групи осіб, залежних від ПАР, нам необхідно було обрати методи, адекватні специфіці цієї групи. Саме від цієї специфіки ми відштовхувались при виборі методів, які у підсумку застосували до обох груп вибірки: і осіб, залежних від ПАР, і осіб, умовно здорових. Слід зазначити, що для осіб, залежних вір ПАР, є характерними: знижена здатність до саморегуляції, невисока вмотивованість до участі у дослідженні, висока реактивність, прояви когнітивних дефіцитів, пов’язаних з тривалою інтоксикацією.

Тому було обрано інструментарій, що враховує такі особливості групи осіб, залежних від ПАР, і відповідає таким вимогам: проведення дослідження має займати небагато часу та одночасно надавати можливість оцінити особистісні характеристики досліджуваного. Крім того, на вибір методів впливала його апробація та адаптація на клінічній вибірці.

Ми зупинились на Theory of Mind assessment scale, скорочено - Th.o.m.a.s [8; 9] для вимірювання ІTC. Врахувавши дані інших авторів про зв'язок між залежністю від ПАР та негативним впливом цього фактора на ділянки мозку, особливості функціонування яких вважаються корелятами ITC та, одночасно, емоційного інтелекту [11], ми також використали Торонтську Алекситимічну шкалу ТАС26, адаптовану в НДІ ім. Бехтерєва [2],

П’ятифакторний особистісний опитувальник 5PFQ, адаптація Хромова [6] був залучений для оцінки зв'язків ITC з особистісними властивостями досліджуваних.

Методика Th.o.m.a.s - це опитувальник, який складається з 39 відкритих запитань (деякі 3 них опціональні, фактично питань у методиці 37), спрямованих на дослідження різних аспектів ITC.

Процедура. Дослідник пропонує ряд запитань, на які респондент відповідає у вільній формі. Якщо досліджуваний має труднощі 3 розумінням питань, дослідник може переформулювати запитання, однак слідуючи вимозі безтенденційності. Якісні дані у подальшому переводяться у кількісні. В оригінальному варіанті форма процедури напівструктуроване інтерв'ю, яке записується та потім передається двом асистентам, які не брали участі в інтерв'ю та які, незалежно один від одного, кодують відповіді за шкалами. В подальшому результати порівнюються. Нами було модифіковано процедуру задля врахування умов проведення. Ми пропонували методику досліджуваним у вигляді суб'єктивного опитувальника у батареї з трьох тестів та короткої анкети. Дослідження проводилось у малих групах для уможливлення фіксації поведінкових реакцій та допомоги у випадку виникнення труднощів з розумінням питань. Групам осіб на більш пізньому етапі одужання та умовно здорових методика пропонувалася у формі онлайн-опитувальника.

Відповідь на кожне запитання може бути оцінена від 0 до 4 балів.

\section{Оцінка 0 балів ставиться:}

- коли досліджуваний мовчить, хоча інтерв'юер заохочує його до відповіді;

- коли відповідь незрозуміло сплутана, або абсолютно не має відношення до питання, або відірвана від реальності.

\section{Оцінка 1 ставиться:} відповіді;

- коли досліджуваний витрачає час, проте фактично не надавши жодної значущої

- коли досліджуваний каже, що не знає, як відповісти, або обмежується відповідями так чи ні, не додавши більше нічого суттєвого;

- коли відповідь $€$ плутаною або суперечливою стосовно запитання;

- коли досліджуваним надається приклад (мимовільно, або за запитом дослідника), який не відповідає самій відповіді.

\section{Оцінка 2 бали присвоюсться за умов:} відповідь;

- відповідь дає відчуття того, що досліджуваний «розгублений», хоча він і надає вірну

- це просто повторення запитання без подальшого розвитку чи пояснення (наприклад, тавтологічна відповідь);

- виражає емоційний тон, який не відповідає питанню (наприклад, емоційно позитивна відповідь на питання, що стосується негативних емоцій);

- неправильно узгоджується з перспективою, яка вимагається запитанням, наприклад, коли питання стосується емоційних станів іншої людини (алоцентрична перспектива), а відповідь стосується лише самого співрозмовника (егоцентрична перспектива). 


\section{Оцінка 3 бали ставиться за умов, якщо:}

- чітко сформульована послідовна відповідь, але надається 3 труднощами, або не розлого (якщо у вигляді інтерв'ю, то після декількох спроб інтерв'юера до уточнення);

- контекст відповідає запитанню, але не має конкретного, змістовного прикладу;

- надається приклад, який є приблизним, загальним, безглуздим або стосується лише поведінки, а не психічних станів чи подій;

- відповідь узгоджена і послідовна, але загальна, стереотипна або лише трохи контекстуалізована.

\section{Оцінка 4 присвоюсться відповіді, яка:}

- є зв'язною, детальною та організованою, із значними, зв'язними та контекстуалізованими прикладами;

- по-різному посилається на власні психічні стани та події досліджуваного, а також на події інших, надаючи, таким чином, не загальну чи суху відповідь, а контекстуалізовану, яка має відношення до особистого досвіду опитуваного.

Шкали тесту.

Шкала А: Я-мене (I-Me) - запитання знаходяться у площині розуміння власних емоцій та їх впливу на респондента, того, наскільки людина гарно розуміє власні емоційні стани, бажання, може вплинути на власний емоційний стан (егоцентрична перспектива), надалі у тексті - ITCA;

Шкала В: Інші-я (Other-Self) - питання лежать у площині того, як добре розуміє респондент емоційні стани інших людей і як вони відображаються у поведінці респондента, того, як гарно респондент може представити емоційні стани, бажання інших людей, а також чи можуть люди впливати на стани інших людей (алокативна перспектива), надалі у тексті - ITCB;

Шкала C: Я-інший (I-Other) - питання лежать у площині, як людина відноситься до гіпотетичних інших і чи розуміє зміну їх емоційних переживань, чи може поставити себе на їх місце та уявити, що вони можуть відчувати, хотіти, чи може респондент вплинути на емоційний стан іншого, його бажання (егоцентрична перспектива), надалі у тексті - ITCC;

Шкала D: Інші-мене (Other-Me) - питання у площині того, як і що респондент думає стосовно відношення інших до його/їі емоційних станів, переживань і поведінки інших по відношенню до нього (алокативна перспектива), надалі у тексті - ITCD [9].

\section{Результати дослідження.}

Перевірка нормальності розподілу вибірки. Оскільки вибірка мала тенденції формування (зокрема, фактори наявності залежності від ПАР), припускаємо, що вона не відповідатиме нормальному розподілу. Для перевірки цього припущення ми використали непараметричній критерій Колмогорова-Смірнова. За результатами (перевірялися показники за основними факторами, а саме, за методикою ТАС 26, 4 шкалами тесту Th.o.m.a.s та основними факторами 5PFQ), виявлено, що за 6 шкалами 3 11-ти вибірка відповідає нормальному розподілу (Sig. 2 tailed $\geq 0.05$ ), виключенням $є$ результати за шкалою ITCA, I-Me, (sig. 2 tailed=0.021); за шкалою ITCC, I-Other, (sig. 2 tailed=0.011); за шкалою ITCD, Other-Me, (sig. 2 tailed=0.028); за другим, «Прив'язаність-Відособленість» (sig. 2 tailed=0.029), та третім, «Самоконтроль-Імпульсивність» (sig. 2 tailed=0.005), факторами опитувальника 5PFQ.

Зв 'язки між ITC та особистісними факторами. Для дослідження зв'язків між ITC та іншими особистісними властивостями, нами було проведено кореляційних аналіз на 98 особах. Оцінювались зв'язки ITC з алекситимією як афективним параметром, пов'язаним 3 вживанням ПАР, а також 3 особистісними факторами, вимірюваними за допомогою особистісного опитувальника 5PFQ. Для кращого розуміння специфіки ITC та ії зв'язків 3 іншими параметрами також проведено кореляційний аналіз за кожною з груп: 1) 3ПАР; 2) АА; 3) УН.

Обрано непараметричний метод кореляційного аналізу, а саме коефіцієнт рангової кореляції r-Спірмена. Причинами його вибору $\epsilon$ те, що: 1) вибірка доволі специфічна, складається, як 3 осіб, залежних від ПАР (тобто, є певний критерій, за яким вона суттєво відрізняється від нормального розподілу), так і осіб, умовно здорових (ця група також специфічна за гендерним та віковим параметрами), що підтвердилося результатами тесту Колмогорова-Смірнова; 2) необхідність прослідковування зв'язків всередині підгруп, які $\epsilon$ невеликими за розміром. Отже, за сукупністю підстав було обрано непараметричний критерій. Крім того, порівнювати виявлені зв'язки за всією групою та підгрупами доцільно, якщо вони вимірювалися за однією логікою. 
Ми оцінювали зв'язки з іншими психологічними факторами інтегративний показник ITC (далі ITCІнтегр), а також основні шкали тесту ITC, а саме ITCA, ITCB, ITCC та ITCD. На усій дослідницькій вибірці $(\mathrm{N}=98)$ отримано ряд статистично значущих зв'язків на рівні тенденції ( $\operatorname{sig} \leq 0.05)$, та на рівні закономірності (sig $\leq 0.01)$.

Зокрема, зі шкалою ITCІнтегр (див. табл.1) виявлено від'ємний помірний зв'язок 3 залежністю від алкоголю $(-, 456 * *)$; від’ємний помірний зв'язок з залежністю від ПАР $(-, 479 * *)$ прямий середній зв'язок 3 параметром статі $(, 532 * *)$; помірний від'ємний зв'язок з параметром віку (-,435**); помірний від’ємний зв'язок з алекситимією $(-, 472 * *)$; прямий слабкий зв'язок 3 другим фактором тесту 5PFQ «Прив'язаність-Відособленість» $(, 272 * *)$ та 3 його четвертою шкалою «Розуміння-Нерозуміння» (,283**); прямий слабкий зв'язок 3 четвертим фактором тесту 5PFQ «Емоційність-Емоційна стриманість» на рівні тенденції $(, 230 *)$, та його шкалами «Тривожність-Безтурботність» $\left(285^{* *}\right)$ та «Емоційна лабільність-Емоційна стабільність» (,229*); прямий помірний зв'язок 3 п'ятим фактором тесту 5PFQ «ЕкспресивністьПрактичність» $(, 482 * *)$, та його шкалами «Допитливість-Консерватизм» (,509**); «Артистичність-Неартистичність» $(, 319 * *)$; «Сенситивність-Нечутливість» $(, 464 * *)$.

Таблиця 1. Кореляції між шкалою шкалами ITC та іншими особистісними властивостями за всією вибіркою

\begin{tabular}{|l|c|c|c|c|c|}
\hline Показники & ITСІнтегр & ITCA & ITCB & ITCC & ITCD \\
\hline Залежність від ПАР &,$- 479^{* *}$ &,$- 362^{* *}$ &,$- 529^{* *}$ &,$- 420^{* *}$ &,$- 451^{* *}$ \\
\hline Залежність від алкоголю &,$- 456^{* *}$ &,$- 449^{* *}$ &,$- 464^{* *}$ &,$- 360^{* *}$ &,$- 342^{* *}$ \\
\hline Стать &, $532^{* *}$ &, $512^{* *}$ &, $474^{* *}$ &, $455^{* *}$ &, $453^{* *}$ \\
\hline Вік &,$- 435^{* *}$ &,$- 501^{* *}$ &,$- 426^{* *}$ &,$- 367^{* *}$ &,$- 299^{* *}$ \\
\hline ТАС26 &,$- 472^{* *}$ &,$- 379^{* *}$ &,$- 412^{* *}$ &,$- 465^{* *}$ &,$- 451^{* *}$ \\
\hline Прив'язаність-Відособленість &, $272^{* *}$ & - & - &, $298^{* *}$ &, $234^{*}$ \\
\hline Самоконтроль-Імпульсивність & - & - & - &, $211^{*}$ &, $251^{*}$ \\
\hline Емоційність-Емоційна стриманість &, $230^{*}$ &, $272^{* *}$ & - &, $216^{*}$ & - \\
\hline Експресивність-Практичність &, $482^{* *}$ &, $411^{* *}$ &, $365^{* *}$ &, $456^{* *}$ &, $441^{* *}$ \\
\hline Допитливітсь-Консерватизм &, $509 * *$ &, $472^{* *}$ &, $397^{* *}$ &, $471^{* *}$ &, $442^{* *}$ \\
\hline Артистичність-Не артистичність &, $319^{* *}$ &, $205^{* *}$ &, $244^{*}$ &, $322^{* *}$ &, $347^{* *}$ \\
\hline Сензитивність-Нечутливість &, $464 * *$ &, $424 * *$ &, $315^{* *}$ &, $440^{* *}$ &, $390^{* *}$ \\
\hline
\end{tabular}

Примітки.

1. Тут і в наступних табл. використано скорочення: ІТСІнтегр - інтегративний показник ITC тесту Th.o.m.a.s; ITCA - шкала A тесту Th.o.m.a.s; ITCB - шкала В тесту Th.o.m.a.s; ITCC шкала C тесту Th.o.m.a.s; ITCD - шкала D тесту Th.o.m.a.s; TAC26 - результат тесту алекситимії Торонтська Алекситимічна шкала TAC26.

2. Символ * відповідає статистично значущому зв'язку на рівні $\operatorname{sig} \leq 0,05$; Символ $* *$ відповідає статистично значущому зв'язку на рівні sig $\leq 0.01$.

Як бачимо у табл. 1, за шкалою ITCA наявні зв'язки, аналогічні попередній шкалі, проте варто зазначити про відмінності у порівнянні з інтегративним показником. Зокрема, наявна слабка пряма кореляція з четвертим фактором тесту 5PFQ «Емоційність-Емоційна стриманість» на рівні закономірності, а не тенденції $(, 272 * *)$, та кореляції з його шкалами «ТривожністьБезтурботність» $\left(, 332^{* *}\right)$ та «Напруженість-Розслабленість» $\left(, 213^{*}\right), 3$ якою зв'язків у інтегративному показнику знайдено не було.

За шкалою ITCB наявні зв'язки, аналогічні попередній шкалі, проте варто зазначити про відмінності у порівнянні з інтегративним показником. Зокрема, знайдено лише помірну пряму кореляцію 3 п’ятим фактором «Експресивність-Практичність» $\left(, 365^{* *}\right)$ та шкалами «Допитливість-Консерватизм» $(, 397 * *)$, «Артистичність-Неартистичність» на рівні тенденції, а не закономірності $\left(, 244^{*}\right)$, та «Сенситивність-Нечутливість» $\left(, 315^{* *}\right)$.

Відмінною рисою зв'язків за шкалою ІТСС в порівнянні з інтегративною шкалою $\epsilon$ те, що за ITCC наявні статистично значущі зв'язки 3 усіма факторами Особистісного опитувальника 5PFQ, окрім першого. Зокрема, виявлено слабкий позитивний зв'язок 3 другим фактором «Прив'язаність-Відособленість» (,298**), слабкий позитивний зв'язок на рівні тенденції 3 третім фактором «Самоконтроль-Імпульсивність» $\left(, 211^{*}\right)$, слабкий позитивний 
зв'язок на рівні тенденції з четвертим фактором «Емоційність-Емоційна стриманість» $\left(, 216^{*}\right)$ та помірний прямий зв'язок з п’ятим фактором «Експресивність-Практичність» $\left(, 456^{* *}\right)$.

Особливістю зв'язків за шкалою ITCD є наявність прямих слабких зв'язків на рівні тенденції з другим та третім факторами опитувальника 5PFQ «Прив'язаність-Відособленість» та «Самоконтроль-Імпульсивність» $(, 234 *)$ та $\left(, 251^{*}\right)$ відповідно. Окрім цього, наявна помірна пряма кореляція з п’ятим фактором «Експресивність-Практичність» $(, 441 * *)$.

Iнші особливості. Цікаву тенденцію знайдено у зв'язках між шкалами тесту ITC та фактором віку (див. табл.1). Зокрема, сила зв'язку значно знижується лінійно, починаючи 3 найбільшої за шкалою ITCA $\left(-, 501^{* *}\right)$ і надалі знижується - за шкалою ITCB $\left(-, 426^{* *}\right)$, за шкалою ITCC $(-, 367 * *)$ та за шкалою ITCD $(-, 299 * *)$. Цю тенденцію спробуємо пояснити нижче при обговоренні результатів.

Результати за групою ЗПАР (N=42). Отримано ряд статистично значущих зв'язків між ITC та іншими психологічними властивостями на рівні тенденції $(\operatorname{sig} \leq 0.05)$ та на рівні закономірності (sig $\leq 0.01)$. Варто зазначити, що лише невелика частина зв'язків $\epsilon$ статистично значущими (табл. 2).

Таблиця 2. Кореляції між параметрами ITC та іншими особистісними властивостями за групою ЗПАР

\begin{tabular}{|l|c|c|c|c|c|}
\hline Показники & ITСІнтегр & ITCA & ITCB & ITCC & ITCD \\
\hline ТАС26 &,$- 336^{*}$ & - &,$- 379^{*}$ &,$- 337 *$ & - \\
\hline Прив'язаність-Відособленість &, $339^{*}$ & - & - &, $402^{* *}$ & - \\
\hline
\end{tabular}

Отже, як бачимо у табл. 2, зі шкалою ITСІнтегр виявлено від'ємний помірний зв'язок 3 алекситимією (-,336*) на рівні тенденції; прямий помірний зв'язок $(, 339 *)$ на рівні тенденції 3 другим фактором особистісного опитувальника 5PFQ «Прив'язаність-Відособленість».

За шкалою ITCA не знайдено статистично значущих зв'язків з іншими психологічними властивостями. За шкалою ITCB виявлено від'ємний помірний зв'язок на рівні тенденції 3 вираженістю алекситимії (-,379*).

За шкалою ІТСС виявлено від'ємний помірний зв'язок на рівні тенденції з вираженістю алекситимії $(-, 337 *)$ та прямий помірний зв'язок 3 другим фактором особистісного опитувальника $5 \mathrm{PFQ}$ «Прив'язаність-Відособленість» $(, 402 * *)$.

За шкалою ITCD не виявлено статистично значущих зв'язків 3 іншими особистісними властивостями.

Результати за вибіркою $\boldsymbol{A A}(\mathrm{N}=15)$. Отримано ряд статистично значущих зв'язків між ITC та іншими особистісними властивостями на рівні тенденції $(\operatorname{sig} \leq 0.05)$, та на рівні закономірності (sig $\leq 0.01)$. За цією групою також статистично значущих зв'язків небагато. Це зв'язки з факторами та шкалами особистісного опитувальника 5PFQ (табл. 3).

Таблиця 3. Кореляції між шкалою шкалами ITC та іншими особистісними властивостями за групою АА

\begin{tabular}{|l|c|c|c|c|c|}
\hline Показники & ITСІнтегр & ITCA & ITCB & ITCC & ITCD \\
\hline Самоконтроль-Імпульсивність &, $700^{* *}$ & - & - & - &, $761^{*}$ \\
\hline Емоційність-Емоційна стриманість &, $565^{*}$ &, $615^{*}$ &, $683^{* *}$ &, $590^{*}$ & - \\
\hline Експресивність-Практичність &, $677^{* *}$ &, $564^{* *}$ & - &, $693^{* *}$ &, $592^{*}$ \\
\hline
\end{tabular}

Як бачимо у табл. 3, зі шкалою ITCІнтегр виявлено сильний позитивний зв'язок 3 третьою шкалою четвертого фактора «Самоконтроль-Імпульсивнсть» $\left(, 700^{* *}\right)$, середній позитивний зв'язок на рівні тенденції з четвертим фактором «Емоційність-Емоційна стриманість» $\left(, 565^{*}\right)$, середній прямий зв'язок з п’ятим фактором «Експресивність-Практичність» $\left(, 677^{* *}\right)$.

За шкалою ITCA знайдено середній позитивний зв'язок на рівні тенденції з четвертим фактором «Емоційність-Емоційна стриманість» $\left(, 615^{*}\right)$ та середній прямий зв'язок на рівні тенденції з п’ятим фактором «Практичність-Експресивність» $\left(, 564^{* *}\right)$.

За шкалою ITCB виявлено середній позитивний зв'язок 3 четвертим фактором «Емоційність-Емоційна стриманість» $\left(, 683^{* *}\right)$.

За шкалою ІТСС виявлено середній позитивний зв'язок на рівні тенденції з четвертим фактором «Емоційність-Емоційна стриманість» $\left(, 590^{*}\right)$ та середній прямий зв'язок на рівні тенденції з п’ятим фактором «Експресивність-Практичність» $(, 693 * *)$. 
За шкалою ITCD знайдено сильний позитивний зв'язок з третьою шкалою четвертого фактора «Самоконтроль-Імпульсивність» $(, 761 *)$ та середній прямий зв'язок на рівні тенденції 3 п’ятим фактором «Експресивність-Практичність» $(, 592 *)$.

Результати за вибіркою УН $(\mathrm{N}=41)$. Отримано ряд статистично значущих зв'язків між ITC та іншими психологічними факторами на рівні тенденції $(\operatorname{sig} \leq 0.05)$, та на рівні закономірності (sig $\leq 0.01)$. Ці результати наведено у табл. 4.

Таблиця 4. Кореляції між шкалою шкалами ITC та іншими особистісними властивостями за групою УН

\begin{tabular}{|l|c|c|c|c|c|}
\hline Показники & ITСНтегр & ITCA & ITCB & ITCC & ITCD \\
\hline ТАС26 & - & - & - & - &,$- 319^{*}$ \\
\hline Екстраверсія-Інтроверсія & - & - & - &, $311^{*}$ &, $338^{*}$ \\
\hline Прив'язаність-Відособленість & - & - & - & - &, $310^{*}$ \\
\hline Експресивність-Практичність &, $334^{*}$ &, $341^{*}$ & - &, $361^{*}$ & - \\
\hline
\end{tabular}

Як бачимо у табл. 4, за шкалами ITCIнтегр та ITCA виявлено помірний прямий зв'язок на рівні тенденції з п’ятим фактором «Експресивність-Практичність» (,334* та, 341* відповідно).

За шкалою ITCC виявлено помірний прямий зв'язок на рівні тенденції з першим фактором «Екстраверсія-Інтроверсія» $\left(, 311^{*}\right)$ та помірний прямий зв'язок на рівні тенденції 3 п’ятим фактором «Експресивність-Практичність» $(, 361 *)$.

За шкалою ITCD виявлено помірний прямий зв'язок на рівні тенденції 3 першим фактором «Екстраверсія-Інтроверсія» $\left(, 338^{*}\right)$, помірний прямий зв'язок на рівні тенденції 3 другим фактором «Прив'язаність-Відособленість» $\left(, 310^{*}\right)$, а також від'ємний помірний зв'язок на рівні тенденції з алекситимією (-,319*).

Обговорення результатів дослідження.

Аналізуючи отримані результати, можемо зробити ряд висновків та припущень. Найбільш сильні зв'язки з інтегративним показником ITC знайдено за параметрами: статі (найсильніший зпоміж інших); п'ятого фактора Особистісного опитувальника 5PFQ «ЕкспресивністьПрактичність»; залежності від ПАР; алекситимією; залежністю від алкоголю. Статистичний рівень значущості за усіма перерахованими параметрами становить (sig $\leq 0.01)$, тобто можемо говорити про доволі сильні зв'язки на рівні закономірності. Інші параметри або відносяться до шкал різних факторів опитувальника 5PFQ, або мають значно нижчий рівень зв'язку. Згідно до вищезазначеного, можемо стверджувати, що ITC вищий у жінок. Також можемо визначити, що краще розуміння переживань, емоцій, переконань та думок інших людей виявляють ті люди, у яких спостерігається суттєво вищий рівень за фактором експресивності.

В той же час, вживання ПАР значно знижує можливості якісної побудови ITC. При цьому з більшою вірогідністю це виявляється за умов залежності від алкоголю. Адже у осіб, залежних від інших ПАР, а також в групі АА статистично значущих зв'язків не виявлено, тому гіпотеза підтверджується частково.

Іншою виявленою тенденцією $є$ те, що зі збільшенням вираженості алекситимії здатність до побудови адекватної ІTC також знижується, що ілюструється як загальними тенденціями, так і тенденціями і групі УН. Відсутність же зв'язків між алекситимією та ІТС у групах осіб, залежних від ПАР, ми пояснюємо тим, що у них статистично збільшений рівень алекситимії, який $є$ одним з симптомів, тісно пов'язаних з залежністю від ПАР на різних етапах одужання, і є важливим показником у діагностиці залежності від ПАР.

Зв'язок 3 фактором «Експресивність-Практичність» ми вважаємо універсальним корелятом тенденцій до здатності більш якісної побудови ITC за умови відсутності вживання ПАР: адже група, учасники якої тільки нещодавно перестали вживати ПАР, - єдина, у якої відсутні зв'язки між шкалами ITC та п’ятим фактором 5PFQ.

Щодо параметру віку, що також статистично пов'язаний з рівнем ITC, наявна цікава тенденція. Так, вік впливає на ITC за усіма шкалами, проте вплив, починаючи від шкали ITCA до ITCD, лінійно знижується від середнього від'ємного до слабкого від'ємного. Ми вважаємо, що порівнювати статистичну значущу відмінність за ITC між групами, у яких є велика вікова негомогенність, найбільш доцільно саме за останніми шкалами, ITCC та ITCD, сила зв'язку з якими помірно слабка та слабка відповідно. Загалом, фактор віку впливає на здатність до якісної побудови ITC негативно. 
Зв'язок між другим фактором 5PFQ «Прив'язаність-Відособленість» та інтегративним показником ITC ми вважаємо особливістю осіб, залежних від ПАР, що лише нещодавно припинили їх вживати, адже всередині груп УН та АА аналогічного зв'язку немає: він наявний лише у групі ЗПАР. Виявлена тенденція також підтверджується тим, що у групі ЗПАР єдиний зв'язок між ITC та 5PFQ спостерігається саме за цим фактором. Зважаючи на відмінні тенденції у інших групах, це дає підстави припустити пов'язаним з фактом вживання ПАР. Це потенційно надає нам вже другий діагностичний критерій, що пов'язує ITC з залежністю від ПАР.

Щодо специфіки зв'язків між іншими психологічними параметрами та окремими шкалами ITC, найбільш цікавою є тенденція зв'язку з декількома факторами 5PFQ шкали ITCC, яка має найбільшу кількість зв'язків з іншими шкалами та завжди має прямий зв'язок хоча 63 одним фактором 5PFQ. Можемо припустити, що шкала ITCC має найбільш виражені біологічні кореляти 3-поміж інших шкал тесту ITC, проте довести чи спростувати цю гіпотезу за наявних методів дослідження та отриманих результатів наразі не можемо.

Якщо у групі УН ІТС пов'язаний лише 3 першим («Екстраверсія-Інтроверсія»), другим («Прив'язаність-Відособленість») та п’ятим («Експресивність-Практичність») факторами на рівні помірно слабких прямих зв'язків, то у групі АА ІТС пов'язаний з третім («СамоконтрольІмпульсивність»), четвертим («Емоційність-Емоційна стриманість») та п’ятим («Експресивність-Практичність») факторами на рівні середніх та сильних зв'язків. Вважатимемо зв'язок у групі АА специфічним для залежних осіб, що мають певний термін тверезості. Також, можливо, у цьому разі відбивається вплив фактора середовища спільноти Анонімних Алкоголіків, а таку велику силу зв'язків можемо пояснити відносно малою вибіркою, проте підтвердити, або спростувати таку гіпотезу також наразі поки що неможливо.

Варто зазначити, що статистично значущі зв'язки між параметрами ITC та статі і віку виявлено при аналізі усієї вибірки та не виявлено окремо у групах УН, АА, ЗПАР, отже, можемо припустити вплив статевої та вікової негомогенності груп. Тому надалі буде актуальним дослідити ці тенденції за допомогою регресійного або факторного аналізу. Іншим актуальним аспектом буде дослідження гомогенних за статтю та віком груп, щоб відхилити вплив даних факторів. Проте, цілком вірогідно, що фактор статі та віку впливали на наявність зв'язків між ITC та цими параметрами несуттєво, а отримані розбіжності можуть бути пояснені тим, що у жінок вищий рівень соціальних навичок, а, також тим, що з віком спостерігаються тенденції, що погіршують здатність до побудови якісної ІТС. Ці ідеї також поки що можемо розглядати лише на рівні гіпотез.

Висновки. На основі отриманих даних при порівнянні осіб, залежних від ПАР, та осіб, що належать до групи умовної норми, ми встановили ряд зв'язків між ITC та іншими психологічними факторами.

Встановлено, що факт залежності від ПАР негативно відображається на ITC. Також виявлено, що чим вищий прояв алекситимії у особи, тим складніше їй буде розуміти думки, почуття, переконання інших, адже такі люди не розуміють, або розуміють з ускладненнями, власні відчуття та емоції. Таким чином, ITC у осіб, залежних від ПАР, вирізняється редукованим розумінням власних емоцій та переживань, що виражається у поганому розрізненні емоційних переживань та фізіологічних проявів організму і в ускладненні розуміння іншого.

ITC найбільше пов'язаний 3 п'ятим фактором Особистісного опитувальника 5PFQ «Експресивність-Практичність», тобто, чим більше особа проявляє свою спонтанність, допитлива, тобто будує більше гіпотез щодо оточуючого світу, має інтенцію до їх перевірки, орієнтується на власні емоції та переживання, тим вищий рівень ITC спостерігатиметься Можна вважати експресивність-практичність першим зовнішнім корелятом з ITC.

Другим зовнішнім корелятом ITC, що більшою мірою виражений на ранньому етапі одужання при залежності від ПАР, можна вважати другий фактор Особистісного опитувальника 5PFQ «Прив'язаність-Відособленість».

Ми припускаємо, що шкала ITCC має найбільш виражені біологічні кореляти та найсильніше вираження у особистісних характеристиках, проте даний аспект відносимо до перспектив подальших досліджень, адже не можемо ні підтвердити, ні спростувати ці припущення на основі результатів даного дослідження.

Фактор віку за силою зв'язку пов'язаний зі шкалами ITC лінійно; найслабшим $є$ цей зв'язок зі шкалою ITCD. Тобто, за умов вікової негомогенності вибірки, якщо даний фактор складно проконтролювати в силу специфіки вибірки або інших причин, найбільш доцільним 
буде порівняння значень між вибірками саме за шкалою ITCD щоб частково проконтролювати імовірний вплив фактору віку (хоча про вплив на даний час стверджувати не можемо).

До перспектив подальших розвідок слід віднести вивчення впливу параметрів статевої та вікової негомогенності та вплив цих факторів на особливості ITC.

Загалом, отримані результати свідчать про взаємозв'язок між ITC та іншими психологічними параметрами, проте важливо дізнатися, чи впливає безпосередньо залежність від ПАР на ІТС, чи існують інші, опосередковані, фактори, внаслідок дії яких спостерігаються отримані тенденції.

\section{REFERENCES}

1. Dubyaga, E.V., \& Mescheryakov, B.G. (2010). Implitsitnaya teoriya razuma: kratkiy obzor. [Theory of Mind: a brief review]. Psihologicheskiy zhurnal Mezhdunarodnogo universiteta prirodyi, obschestva $i$ cheloveka - Psychological journal of International University of nature, society and human, Dubna, (1). URL: https://psyanima.su/journal/2010/1/2010n1a4/2010n1a4.pdf. [in Russian].

2. Eres'ko, D.B., Isurina, G.S., Kojdanovskaja, E.V., Karvasarskij, B.D., Karpova, Je.B., Korepanova, T.G., \& Shifrin V.B. (2005). Aleksitimija $i$ metody ee opredelenija pri pogranichnyh psihosomaticheskih rasstrojstvah: Metodicheskoe posobie [Alexithymia and methods of its definition at borderline psychosomatic disorders: Methodical manual]. Sankt-Peterburg: Sankt-Peterburgskij nauchnoissledovatel'skij psihonevrologicheskij institut im. V. M. Behtereva [in Russian].

3. Husak, P.M., Martyniuk T.A., \& Sydoruk I.I. (2013). Profilaktyka vzhyvannia psykhoaktyvnykh rechovyn pidlitkamy [Prevention of substance use by adolescents]. Lutsk: Vezha-Druk [in Ukrainian].

4. Martsenkovskyi, I.A., \& Martsenkovska, I.I. (2019). Stabilizatory nastroiu: dyskusiini pytannia terapii alkoholnoi zalezhnosti. [Mood stabilizers: controversial issues in the treatment of alcohol dependence]. Mizhnarodnyi nevrolohichnyi zhurnal - International neurological journal, 3, 70-76 [in Ukrainian].

5. Pinchuk, I.Ja., Kolodezhnij, O.V., Petrichenko, O.O., Zdorik, I.F. (2017). Analiz statistichnih pokaznikiv rozladiv psihiki ta povedinki vnaslidok uzhivannja psihoaktivnih rechovin u 2015-2016 rokah [Analysis of statistical indicators of mental and behavioral disorders due to the use of psychoactive substances in 20152016]. Arhiv psihiatrii - Archive of psychiatry, 23(4), 252-260 [in Russian].

6. Hromov, A.B. (2000). Pjatifaktornyl oprosnik lichnosti: Uchebno-metodicheskoe posobie [Five-factor personality questionnaire: Textbook]. Kurgan: Izd-vo Kurganskogo gos. Universiteta [in Russian].

7. Voznyi, D.V. (2013). Psykhoemotsiini osoblyvosti cholovikiv, khvorykh na alkoholnu zalezhnist [Psychoemotional features of men with alcohol dependence]. Zahalna patolohiia ta patolohichna fiziolohiia General pathology and pathological physiology, 8(3), 97-101 [in Ukrainian].

8. Bosco, F.M., Capozzi, F., Colle, L., Marostica, P., \& Tirassa, M. (2014). Theory of mind deficit in subjects with alcohol use disorder: an analysis of mindreading processes. Alcohol and Alcoholism, 49(3), 299-307.

9. Bosco, F.M., Gabbatore, I., Tirassa, M., \& Testa, S. (2016). Psychometric properties of the Theory of Mind Assessment Scale in a sample of adolescents and adults. Frontiers in psychology, 7(7), 1-12.

10. Goldman, A. (2012). Theory of Mind. Oxford Handbook of Philosophy and Cognitive Science., (pp. 402 424). Oxford: Oxford University Press.

11. Gweon, H., \& Saxe, R. (2013). Developmental cognitive neuroscience of theory of mind. Neural circuit development and function in the brain, 3, 367-377.

12. Jacobs, E., \& Nader-Grosbois, N. (2020). Affective and Cognitive Theory of Mind in children with intellectual disabilities: how to train them to foster social adjustment and emotion regulation. J. Educ. Train. Stud, 8, 80-97.

13. Onuoha, R.C., Quintana, D.S., Lyvers, M. \& Guastella, A.J. (2016). A Meta-analysis of Theory of Mind in Alcohol Use Disorders. Alcohol and Alcoholism, 51(4), 410-415. doi: 10.1093/alcalc/agv137.

14. Premack, D., \& Woodruff, G. (1978). Does the chimpanzee have a theory of mind? Behavioral and brain sciences, 1(4), 515-526.

15. Schiffer, B., Pawliczek, C., Müller, B.W., Wiltfang, J., Brüne, M., Forsting, M., ... \& Hodgins, S. (2017). Neural mechanisms underlying affective theory of mind in violent antisocial personality disorder and/or schizophrenia. Schizophrenia bulletin, 43(6), 1229-1239.

16. Sprong, M., Schothorst P., Vos, E., Hox, J., \& Engeland, H. (2007). Theory of mind in schizophrenia: meta-analysis. British Journal of Psychiatry, 191, 5-13. 